\title{
Okul Müdürlerinin Öğretmenleri, Öğrencileri ve Velileri İkna Etmede Zorlandıkları Konular ${ }^{1}$
}

\author{
Dilgün DAĞ \\ Mersin Üniversitesi \\ ndag@mersin.edu.tr \\ (iD Deniz KAHRIMAN PAMUK \\ Mersin Üniversitesi \\ denizkahriman@gmail.com \\ Soner Mehmet ÖZDEMİR \\ Mersin Üniversitesi \\ sonerozdemir@mersin.edu.tr
}

Gönderilme Tarihi: 22/09/2020

Kabul Tarihi: $23 / 10 / 2020$

Yayınlanma Tarihi: $30 / 11 / 2020$

DOI: $\underline{10.30855 / \text { gjes.2020.06.03.002 }}$

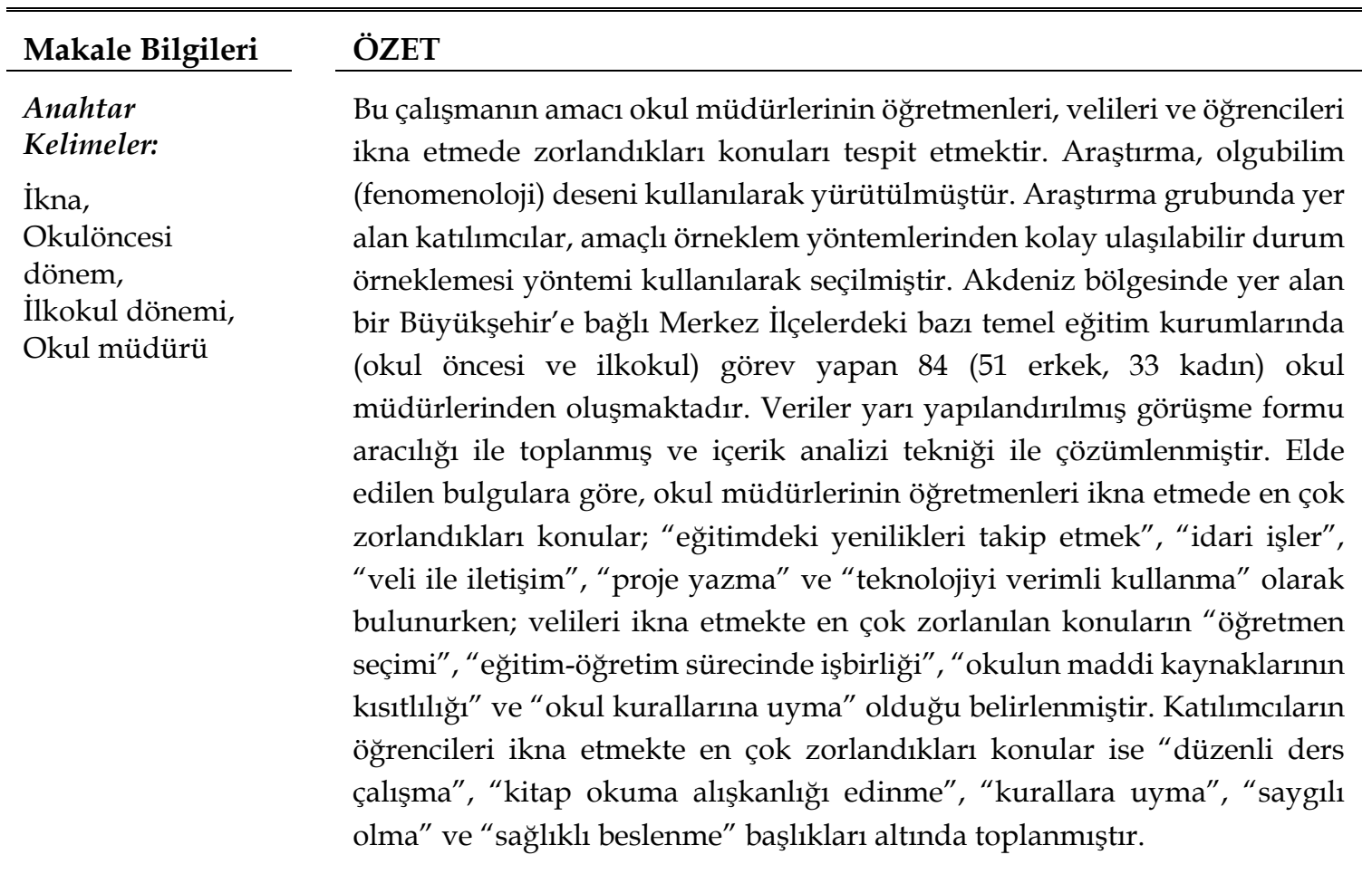

${ }^{1}$ Bu çalışmanın verilerinin bir kısmı II. Uluslararasi Temel Eğitim Sempozyumunda bildiri olarak sunulmuştur.

Dağ, N., Kahriman Pamuk, D. \& Özdemir, S.M. (2020). Okul müdürlerinin öğretmenleri, öğrencileri ve velileri ikna etmede zorlandıkları konular. Gazi Eğitim Bilimleri Dergisi, 6(3), 277299.

DOI: https://dx.doi.org/110.30855/gjes.2020.06.03.002

Dergi Web Sayfası: http://dergipark.gov.tr/gebd 


\section{Issues That School Principals Have Difficult to Persuade Teacher, Students and Parents}

\begin{tabular}{ll}
\hline \hline Article Info & ABSTRACT \\
\hline Keywords: & The aim of this study is to identify the issues that school principals have \\
Persuasion, & difficulty in persuading teachers, parents and students. The study was \\
Pre-school & carried out adapting phenomenology design. Participants in the study \\
period, & group were selected using the convenience sampling method. It consists \\
Primary school & of 84 (51 males, 33 females) school principals (preschool and primary \\
period, & school) in the Central Districts of a Metropolitan city in the \\
School pirinciple & Mediterranean region. The data were collected through a semi- \\
& structured interview form and analysed by content analysis technique. \\
& $\begin{array}{l}\text { According to the findings, the subjects that school principals have } \\
\text { difficulty in persuading teachers are "following innovations in } \\
\text { education", "administrative affairs", "communication with parents", } \\
\text { "writing projects" and "using technology efficiently". "Not to select } \\
\text { classroom teachers", "collaboration for teaching and training", } \\
\text { "limitation of the financial resources of the school" and "obeying the } \\
\text { school rules" are the most mentioned issues by principals as to persuade } \\
\text { parents. Finally, the subjects that the participants had difficulties in } \\
\text { persuading the students were gathered under the titles of "studying } \\
\text { regularly", "reading books", "obeying the school rules", "behaving in a } \\
\text { respectful manner" and "healthy eating. }\end{array}$ \\
\end{tabular}

\section{GİRIŞ}

İkna her yerdedir. Politikada, dinde, sağlıkta, psikoterapide, eğitimde, reklâmcilıkta, satış ve pazarlama sektöründe, halkla ilişkilerde ve günlük sosyal etkileşimde önemli bir rol oynar. Psikoterapide hastanın tedaviye ihtiyacı olduğunu kabul etmesi, terapide direnç göstermemesi, davranışlarını değiştirmesi gibi birçok konuda ikna olması gerekir. Dinlerde, o dinin mensuplarının ilâhî emir ve yasaklar hakkında ikna edilmeleri gerekir. Ki, dinlerde imân ikna ile başlar. Politik sistemlerde, bilhassa demokratik rejimlerde halkın belli bir partinin ideolojisi doğrultusunda doğru stratejiler kullanılarak (Büyükkantarcıoğlu ve Yarar, 2006) ikna edilmesi şarttır. Tüketicilerin düşünceleri ve yaşam biçimleri üzerinde etki yaratarak davranışlarına yön vermede, reklâmlar önemli bir ikna aracı olarak kullanılır. Yine, bir ürünün satışında ve pazarlanmasında iknanın ve ikna stratejilerinin rolü büyüktür. Eğitimde ise öğrencilerin derslere karşı olumlu bir tutum geliştirmeleri, göç ve göçmenler hakkındaki fikir ve inançlarını değiştirmeleri, daha fazla kitap okumaya teşvik edilmeleri; öğretmenlerin ise kişisel ve mesleki gelişmelerine ihtimam göstermeleri, yenilikleri takip etmeleri gibi hususlarda ikna edilmeleri elzemdir. Bu bağlamda öğretmenlerin "ikna" ile tanışmaları ve ikna sürecinde doğru stratejileri kullanmaları şarttır. 
Bilindiği üzere öğretmenler, birden fazla rolü üstlenmek zorundadır. İkna edicilik, bu rollerden biri olup öğretmenin öğretme sanatına kuvvet veren ana kolonu oluşturur. Ki öğretim, bir ikna etme eylemidir (Willingham, 2009, 162). Ve ikna, öğretmenlerin öğrencileri motive etmelerinde, argümanlar ve kanıtlar sunarak öğretim gerçekleştirmelerinde mühim bir kalite belirtecidir.

İkna, aynı zamanda -hem ikna edenin hem de ikna edilenin ihtiyaçlarını karşılayanetkileşimli/interaktif bir süreçtir. Öğretmen ve öğrenci(ler) arasındaki ilişki kadar öğrencilerin ve öğretmenlerin okul yöneticileriyle olan ilişki ve etkileşimlerinde de hayati bir rol oynar. Dolayısıyla ikna edicilik bakımından öğretmenler kadar okul yöneticilerinin de beceriyle donanık olması şarttır. Okul yöneticilerinden okul vizyonunu tasarlamak, sosyal ilişkileri tanımlamak, okul güvenliğine önem vermek, okul çalışanları ile etkili ve uyumlu iletişim sağlamak gibi çağdaş liderlik rollerini üstlenmeleri beklenir (Şişman, 2002). İkna, bu beklentileri hayata geçirme noktasında okul yöneticileri için büyük bir avantaj sağlar.

Antik Çağ filozofları başta olmak üzere Batılı düşünürler, ikna kavramı ile yoğun bir şekilde ilgilenmişlerdir. İknanın Antik Çă̆' daki ilk savunucularından biri olan Aristoteles (2008, 38), ikna edici bir konuşmanın üç bileşenini (ethos, pathos, logos) ortaya koymuştur. İkna, Sofistlerin öğrettiği en büyük becerilerden biridir. Yine, 20. yy'ın başlarından itibaren psikoloji, sosyoloji, siyaset bilimi, antropoloji ve iletişim de dâhil olmak üzere sosyal bilimlerin neredeyse tüm alanlarında ikna odaklı çalışmalar yapılmıştır. Ancak ikna konusundaki ulusal literatür zayıftır. Ulusal alanyazında ikna, bilhassa eğitim alanındaki araştırmalara pek fazla konu olmamış görece yeni bir inceleme konusudur. Bu yönüyle bu araştırmanın alanyazına bir yenilik getireceği ve bazı açılımlara katkı sağlayacağı umulmaktadır.

İkna, kişisel ve profesyonel yaşamın odağında yer alan bir olgudur. İnsanların kahir ekseriyeti, bilinçli bir şekilde ikna ile meşgul olduğunu fark etmese de ikna hep bizimledir. Bilgiye erişimin oldukça kolaylaştığı bugünün dünyasında ikna bambaşka kurallarla çalışmaktadır (Dă̆, 2019). Bundan ötürü eğitim alanında ikna etmenin-edilmenin altında yatan psikolojik süreçlerin, ikna etme taktiklerinin, ikna etmede-edilmede zorlanılan hususların bilinmesi ve ortaya konması, ikna edici bir dil ve üslup inşa etme gereğinin fark edilmesi, genel ikna yasalarının araştırılması, ikna sürecinin ve ilkelerinin anlaşılması elzem bir ihtiyaçtır. Kaldı ki 21. yy, ikna ve etki sanatında ustalaşmalarını insanlara adeta şart koşmaktadır.

\section{İkna}

İkna, Batıda kapsamlı psikolojik araştırmaların odağı olmuş bir olgudur. Terimsel açıdan birinin/grubun fikrini ve tutumunu değiştirme potansiyelini tanımlayan bir prosedürü ifade eder. Birini bir konuda inandırma ve bir şey yapmaya razı etmedir (Yüksel, Sandıkçıŏglu, Onay 
ve Yılmaz, 1994, 29). Daha açık bir ifadeyle ikna, bir kişinin ya da grubun başka bir kişiye, gruba, olaya, nesneye ya da düşünceye yönelik tutum, inanç ve davranışlarını etkilemek için yazılı veya sözlü iletişim yoluyla kasıtlı ve başarılı çabalar gösterme kabiliyetidir. Düşünmede, yazmada ve konuşmada kapasite/potansiyel ve maharet gerektiren bir beceridir. Hedefin aklını ve kalbini kazanmaya çalışmak, tutum değişikliğini tetiklemek, düşüncelerini şekillendirmek, güçlendirmek ya da değiştirmek bittabi bir meziyettir.

İkna, aynı zamanda bir sanattır; insanların yapmalarını istediğiniz şeyi yapma ve sevmelerini sağlama sanatıdır. Ve Arizona Amerikan Üniversitesi Psikoloji Derneği'nin 125. Yıllık Kongresi'nde Psikoloji ve Pazarlama Danışmanlığı yapan Robert Cialdini'nin (2003) de dile getirdiği gibi artık sadece bir sanat değildir; bilimdir de. Şayet birinin nasıl ve ne şekilde ikna olabileceği konusunda hipotezler yaratılabiliyor ve test edilebiliyorsa, ikna sanat olduğu kadar da bilimdir. Bilgi gerektiren bilinçli bir girişimdir ve öğrenilebilen ve geliştirilebilen bir süreci vardır. Bir açıdan da ikna, toplum hayatı ve demokrasi için önem taşıyan bir kavramdır. Bir sosyal kontrol mekanizmasıdır. Ve bir yönetim aracıdır. Duygu ve düşüncelere hitap etmeye dayalı bir eylem çağrısıdır. Bilhassa demokratik rejimlerde başat öneme sahiptir ve siyasetin en önemli unsurlarından biridir. Zira politika, ikna etme sanatı olarak tanımlanır.

Modern dünyada ikna edici olmak, rasyonel açıdan değerlendirildiğinde etik bir zorunluluk gibi görünmektedir. Ama bütün iknalar etik değildir. Hatta zorlama, beyin yıkama ve işkence gibi bazı ikna yöntemleri tamamen etik dışıdır. Tam da bu sebepten ötürü bazı düşünürler, ikna etmenin doğası gereği etik olmadığını; fakat doğası gereği kaçınılmaz olduğu kanaatini taşırlar. Nitekim insan davranışı, çeşitli ikna biçimlerinden etkilenir. Mantıklı bir argüman ileri sürme, duygulara hitap etme, bir uzmanın ya da otorite figürünün yönlendirmesi gibi taktikler, ikna olma sürecine kuvvet verir. İnsanların büyük çoğunluğunun iktidar olduklarını düşündüklerine olumlu cevap verme gibi bir durumları da söz konusudur. Yani, gücü taklit etmek veya gücün görüntüsünü vermek de ikna olmaya/etmeye yetmektedir. Nüfuzun ve paranın bir güç ve ikna faktörü olarak kullanılması hayli yaygın bir vakıadır. Çünkü para ve nüfuz, çoğu insanın ikna ufkunun belirleyicisidir (Dă̆, 2019).

İkna, bir veri dökümü değildir. Daha açık bir söylemle verileri, bilgileri veya mesajları ikna edilmeye çalışılan kimselere boşaltmak/boca etmek demek değildir. İkna, inandırmaya veya razı etmeye dayanan ve düşünme, hissetme ya da hareket etme şeklini değiştirmeyi amaçlayan (Simons, Morreale ve Gronbeck, 2001, 7) bir prosedüre sahiptir. Kişiye nedenler, kantlar ve argümanlar sunarak ikna etmek zorlayarak, manipüle ederek ve aldatarak ikna etmekten daha ahlâkî bir alternatiftir. Ayrıca birisini bir şeyi yapmaya rasyonel olarak ikna etmek, onu paternalist hareket etmekten korumaktır. 
İkna etme yeteneği, karar vericinin ikna edicinin bakış açısına "evet" demesiyle ölçüldügüünden ikna doğası gereği iletişimsel ve etkileşimseldir. Etkileşimli bir süreç olması ve tarafların ihtiyaçlarını karşılamaya çalışması dolayısıyla propagandadan ayrışır. Propaganda, mesajların hedef kitleye tek taraflı olarak iletilmesi sürecidir. Propagandada ikna edici stratejiler kullanır; ancak, amaç boyutu bakımından ikna etme sürecinden farklıdır. İkna ise, iletişimsel bir süreçtir; hatta iletişimin bir alt kümesidir (Jowett ve O'Donnell, 2012, 2). Retorik, hem ikna hem de propaganda sürecinde önemli bir referanstır. Bu bağlamda çalışmanın amacı, ilkokul ve okul öncesi eğitim kurumu müdürlerinin öğretmenleri, velileri ve öğrencileri ikna etmede zorlandıkları konuları tespit etmektir.

\section{YÖNTEM}

$\mathrm{Bu}$ çalışma, nitel araştırma modeline dayalı olarak yürütülmüştür. Nitel araştırma, Creswell'in (2007) belirttiği gibi, bir olguyu katılımcıların bakış açılarından görebilmeyi, onların bakış açısına ait süreçleri ortaya koymayı ve detaylı veri toplamayı amaçlayan bir araştırma modelidir. Nitel araştırmalarda, verilerin olabildiğince ayrıntılı ve doğrudan sunulması önemlidir.

Çalışmada nitel araştırma desenlerinden birisi olan fenomenoloji (olgubilim) deseni kullanılmıştır. Fenomenoloji bir felsefe, yöntem ve yaklaşımdır (Patton, 1990). Bir felsefe olarak fenomenoloji, insan bilinci olgusuyla ilgilidir. Bilimsel bir araştırma metodolojisi olaraksa insan deneyimlerinin anlamları üzerine odaklanır (Von Eckartsberg, 1986). Olgu bir duygu, ilişki, program, organizasyon ya da kültür gibi bir varlık olabilir. Fenomenologlar "bu olguyu deneyimleyenler için deneyimin özü nedir?" sorusunu sorarlar (Patton, 1990) ve bu deneyimlerin örtülü yapısını ve anlamını ortaya koymayı amaçlarlar. Fenomenoloji, sıradan gözlemlerle ortaya çıkarılamayan şeylerin özü arayışıdır. Dolayısıyla tanımlayıcı bir araştırma desenidir. Farkında olduğumuz, ancak derinlemesine ve ayrıntılı bir anlayışa sahip olmadığımız olgulara odaklanır (Akturan ve Esen, 2008; Creswell, 2007). Bu çalışmada araştırılan olgu, "ikna" dır. İlkokul ve okul öncesi eğitim kurumlarında görev yapan müdürlerin öğretmenleri, velileri ve öğrencileri ikna etmede zorlandıkları konuların veya durumların ortaya çıkartılması amaçlandığı için bu desen tercih edilmiştir.

\section{Çalışma Grubu}

Olgu bilim araştırmalarında veri kaynakları, "araştırmanın odaklandığı olguyu yaşayan ve bu olguyu dişa vurabilecek veya yansıtabilecek bireyler ya da gruplardır" (Yıldırım ve Şimşek, 2013, 74). Araştırma, hem çalışma amacı hem de araştırma deseni dikkate alınarak 2019-2020 eğitim-öğretim yılı güz yarıyılında Akdeniz bölgesinde yer alan bir Büyükşehir'e bağlı Merkez İlçelerdeki bazı ilkokul ve okul öncesi eğitim kurumlarında görev yapan okul müdürleri ile yürütülmüştür. Çalışma grubunun oluşturulmasında kolay ulaşılabilir durum örneklemesi tercih 
edilmiştir. Kolay ulaşılabilir durum örneklemesi araştırmacılara yakın olan ve erişilmesi kolay olan bir durumu inceleme fırsatı vererek sürecin hızlı ve pratik bir şekilde yürütülmesini sağlar (Yıldırım ve Şimşek, 2008). Bunun yanı sıra, kolay ulaşılabilir durum örneklemesi maliyet ve zaman açısından araştırmacılara kolaylık sağlayan bir örnekleme çeşididir (Patton, 1990). Bu araştırmada da okul müdürleri gönüllü olarak araştırma sürecine dâhil olmak istemişlerdir.

Araştırmanın çalışma grubunu toplam 84 okul müdürü oluşturmuştur. Katılımcıların 51'i ilkokul (40'ı erkek-17'si kadın), 33'ü (17'si erkek-16'sı kadın) okulöncesi eğitim kurumunda çalışmaktadır. Okul müdürlerinin çoğunluğunun erkek olduğu görülmektedir. İlkokulda müdürlerinin yaş ortalaması 40'ın üstünde iken okulöncesi yöneticilerinin yaş ortalaması 40'a yakındır. Yine ilkokul yöneticilerinin öğretmenlik ve yöneticilik tecrübeleri ile mesleki kıdemleri okulöncesi yöneticilerine göre daha yüksektir. Katılımcılara ilişkin bilgiler, Tablo 1'de sunulmaktadir.

Tablo 1.

Katılımcılara İlişkin Betimsel Özellikler

\begin{tabular}{lccc}
\hline Kategori & & İlkokul & Okul Öncesi \\
\hline Cinsiyet & Kadın (n) & 11 & 16 \\
& Erkek (n) & 40 & 17 \\
Yaş ortalaması & & 45,78 & 39,61 \\
Öğretmenlik tecrübesi & & 12,41 & 8,49 \\
Yöneticilik tecrübesi & & 11,78 & 7,27 \\
Mesleki kıdem yılı & & 21,75 & 15,30 \\
\hline
\end{tabular}

Ayrıca katılımcıların gerçek isimleri yerine ilkokul müdürleri için "Mi”, okul öncesi müdürleri için "MOÖ" takma isimleri kullanılmıştır.

\section{Verilerin Toplanması}

Veriler, açık uçlu yarı-yapılandırılmış görüşme formu aracılığıyla çalışma grubunun büyüklüğü gözetilerek online görüşme formu yoluyla yazılı olarak bir haftalık süre zarfında toplanmıştır. Görüşmeler, gözlemlenemeyen davranışları bireylerin sahip oldukları duyguları ve anlayışları kendi cümleleriyle açıklayacakları bir çatı sunarak dünyayı nasıl gördüklerini, kişisel bakış açılarını ve deneyimlerini anlamayı sağlar (Patton, 1990). Bu çalışmada görüşme tekniğinin tercih edilmesi nedeni, temel eğitim kurumlarında görev yapan okul müdürlerinin tecrübelerine dayalı olarak görüşlerini ilk elden ulaşılan verilerle değerlendirebilmektir.

Araştırmacılar, görüşme sorularıyla ilgili olarak birbirlerinden bağımsız olarak bir ön çalışma yapmış ve ön çalışmalar sonucunda ortaya koydukları görüşme sorularını yaklaşık 2 saat süren odak grup toplantılarında tartışmış ve nihai sorulara karar vermişlerdir. Araştırmacılar görüşme sorularını kişisel gözlemlerinden, ulusal ve uluslararası alanyazın incelemesinden ve sınıf içi yaşantılarından hareketle ortaya koymuşlardır. Görüşme soruları biri eğitim psikolojisi, 
ikisi eğitim yönetimcisi üç uzmanın görüşüne sunulmuş (Glesne, 2013), gelen eleştiri ve öneriler doğrultusunda düzenlenmiş ve mini bir pilot uygulama yapılmıştır. Pilot uygulama formu, 5 ilkokul ve 5 okul öncesi kurum müdürüne uygulanmıştır. Uygulama sonucunda değerlendirme yapılmış ve görüşme formuna nihai şekli verilmiştir. Görüşmelerde okul müdürlerine yöneltilen sorular şu şekildedir:

1) Öğretmenleri ikna etmede en çok zorlandığınız konular nelerdir, örnekler vererek açıklar misiniz?

2) Velileri ikna etmede en çok zorlandığınız konular nelerdir, örnekler vererek açıklar mısınız?

3) Öğrencileri ikna etmede en çok zorlandığınız konular nelerdir, örnekler vererek açıklar misiniz?

Bu soruların yanı sıra toplanan verilerin derinliğini arttırmak amacı ile sondaj sorular da eklenmiştir. Online veri toplama süreci 10-17 Kasım 2019 tarihleri arasında gerçekleştirilmiştir. Görüşme sorularının yer aldığı online form okul müdürlerine e-posta yolu ile iletilmiş, yanıtlar yine e-posta aracılığıyla alınmıştır.

\section{Verilerin Analizi}

Olgu bilim araştırmalarında elde edilen verilerin analizi, yaşantıları ve anlamları ortaya çıkarmaya yöneliktir (Yıldırım ve Şimşek, 2013, 75). Veriler, içerik analizi yöntemi kullanılarak analiz edilmiştir. İçerik analizinde amaç, verileri açıklayabilecek kavram ve ilişkilere ulaşmaktır. Verilerin analizinde bulunan temel anlamlar, "tema" olarak isimlendirilir (Patton, 1990). Bu çalışmada elde edilen veriler temalandırılmıştır. Bunun için öncelikle ham veriler araştırmacılar tarafından ayrı ayrı okunmuş, taslak temalar belirlenmiş ve okul müdürlerinin verdikleri yanıtlar kodlanmıştır. Araştırmacıların kodlamaları karşılaştırılmış ve Miles ve Huberman (1994) tarafından ortaya konan "Güvenirlik = (Görüş Birliği) / (Görüş Birliği + Görüş Ayrıllı̆̆ı) x 100" formülü ile uzlaşma yüzdesi \%95 olarak hesaplanmıştır. Fikir ayrılığına düşülen kodlamalar tekrar incelenmiş, tartışılmış ve fikir birliğine varılarak temalara, alt temalara ve kodlamalara nihai hâli verilmiştir. Her bir araştırma sorusu altında yer alan temalar ve kodlamalar, tablolar hâlinde sunulmuş ve okul müdürlerinin görüşlerine doğrudan alıntılar yoluyla yer verilmiştir.

\section{Geçerlik ve Güvenirlik Çalışmaları}

Çalışmanın geçerliliğini arttırmak için görüşmelerden elde edilen veriler ayrıntılı olarak ve doğrudan alıntılar şeklinde rapor edilmiştir. Çalışmanın güvenirliğini arttırmak içinse teyit incelemesi yapılmıştır. Araştırmacılar, birbirlerinden bağımsız biçimde görüşme kayıtlarıyla ilgili iki haftalık bir ön çalışma yapmış; kodları ve temaları tespit etmişlerdir. Ön çalışma sonucunda ortaya çıkan temalar, iki hafta boyunca 60 ila 90 dakika arasında süren odak grup toplantılarında tartışılmış, değerlendirmelerde bulunulmuş ve fikir birliğine ulaşılmıştır. Araştırmacıların elde ettiği temalar, alanda uzman bir başka araştırmacı tarafından tekrardan 
kodlanmış ve elde edilen sonuçlar karşılaştırılmıştır. Araştırmanın güvenirlik hesaplaması için Miles ve Huberman'ın (1994) önerdiği aşağıdaki uyuşum yüzdesi kullanılmıştır:

Güvenirlik $=($ Görüş Birliği $) /($ Görüş Birliği + Görüş Ayrıllğı $) \times 100$

$\mathrm{Bu}$ formül kullanılırken araştırmacıların, okul müdürlerinin ifadeleri için aynı kodu kullandıkları durumlar görüş birliği, farklı kodu kullandıkları durumlar ise görüş ayrılığı olarak kabul edilmiş̧ir. Ardından araştırmacıların yaptığı kodlamalar karşılaştırılmıştır. Yapılan hesaplamalar sonucunda araştırmada uyuşum yüzdesi .95 olarak hesaplanmıştır. Bu işlem sonucunda elde edilen uyuşum yüzdesinin \%70' in üzerinde çıkması, veri toplama aracından elde edilen verilerin güvenilir kabul edildiği (Miles ve Huberman, 1994) anlamına gelmektedir.

\section{BULGULAR}

Araştırmada yapılan içerik analizi sonucunda 3 kategoriye, 14 farklı koda ulaşılmıştır. Elde edilen tema, kategori ve kodlar Tablo 2'de sunulmaktadır.

\section{Tablo 2.}

Okul Müdürlerinin Öğretmenleri, Velileri, Öğrencileri İkna Etmede Zorlandıkları Konular

\begin{tabular}{|c|c|c|c|c|c|}
\hline Tema & Kategori & Kod & $\begin{array}{c}\text { Okul } \\
\text { Öncesi }\end{array}$ & İlkokul & $\mathbf{f}$ \\
\hline & \multirow{6}{*}{ Öğretmen } & Eğitimdeki yenilikleri takip etme & 14 & 16 & 30 \\
\hline & & İdari İşler & 10 & 13 & 23 \\
\hline & & Veli ile İletişim & 9 & 6 & 15 \\
\hline & & Proje Yazma & 8 & 7 & 15 \\
\hline & & Teknolojiyi verimli kullanma & 6 & 6 & 12 \\
\hline & & Yok & 4 & 6 & 10 \\
\hline & \multirow{4}{*}{ Veli } & Öğretmen Seçimi & 6 & 15 & 21 \\
\hline & & Eğitim- Öğretim Sürecinde İşbirliği & 8 & 12 & 20 \\
\hline & & Okulun Maddi Kaynaklarının Kısıtlılığı & 12 & 6 & 18 \\
\hline & & Yok & 10 & 3 & 13 \\
\hline & \multirow{5}{*}{ Öğrenci } & Düzenli ders çalışma & - & 24 & 24 \\
\hline & & Kitap Okuma Alışkanlığı & - & 15 & 15 \\
\hline & & Kurallar & 2 & 13 & 15 \\
\hline & & Sayg1lı olma & 1 & 11 & 12 \\
\hline & & Sağlıklı Beslenme & 9 & 2 & 11 \\
\hline
\end{tabular}

Tablo 2'de görüldüğü üzere okul müdürlerinin öğretmenleri ikna etmede en çok zorlandıkları iki konu, "eğitimdeki yenilikleri takip etme" ve "idari işler" dir. Velileri ikna etmede zorlandıkları konular, ilkokul ve okulöncesi eğitim kurumu müdürlerine göre değişiklik göstermiştir. İlkokul müdürlerinin velileri "öğretmen seçimi"; okul öncesi eğitim kurumu müdürlerinin ise, "okulun maddi kaynaklarının kısıtlılığı" konusunda ikna etmekte zorlandıkları tespit edilmiştir. Yine öğrencileri ikna etmede zorlandıkları hususlar bakımından okul müdürleri arasında farklılık olduğu görülmüştür. Okul öncesi eğitim kurumu müdürlerinin öğrencileri 
"sağlıklı beslenme"; ilkokul müdürlerinin ise, "düzenli ders çalışma" konusunda ikna etmede zorlandıkları saptanmıştır.

\subsection{Okul Müdürlerinin Öğretmenleri İkna Etmede Zorlandıkları Konular}

İlk araştırma sorusunda, okul müdürlerinin öğretmenleri ikna etmede zorlandıkları konulara ilişkin görüşleri incelenmiştir. Araştırmaya katılan 84 okul müdüründen $74^{\prime}$ ü öğretmenleri ikna ederken "eğitimdeki yenilikleri takip etme", "idari işler", "veli ile iletişim", "proje yazma", "teknoloji”yi verimli kullanma konularında zorlandıklarını belirtirken; 10'u hiçbir konuda zorlanmadığını belirtmiştir. Okul müdürlerinin öğretmenleri ikna etmekte zorlandıkları konular genel olarak değerlendirildiğinde, "eğitimdeki yenilikleri takip etme" en sık tekrar edilen tema olarak ortaya çıkmıştır. Aşağıda bu kodlara ilişkin açıklama örneklerine yer verilmektedir.

Okul müdürleri tarafından öğretmenleri ikna etme konusunda en sık dile getirilen konu, “eğitimdeki yenilikleri takip etme" ye (f:30) ilişkindir. Okul öncesi müdürü MOÖ12 ve MOÖ33 bu konu ile ilgili görüşünü şu sözlerle dile getirmiştir:

“Güncellenen eğitim programından haberi olmayan öğretmen var, kazanım göstergelerden haberi yok mesela. Bazı okullarda alternatif eğitim yaklaşımları uygulanırken ben öğretmenlerimi kafalarındaki kalıplardan kurtaramıyorum.".

“Öğretmenlerimizin birçoğu çocukları hâlâ eski çocuklar sanıyor, hiçbir güncel yaklaşımı takip etmiyorlar. Örneğin yaşça büyük öğretmenlerin çocuk merkezli yaklaşımdan haberi yok, öğrenme merkezi ne bilmiyor. Çoğu kez MEB'in güncellediği ve uygulanmasını istediği eğitsel süreçlerden bile bizim aracilığımızla haberleri oluyor ve ona rağmen uygulamiyorlar.".

İlkokul müdürü Mi12 ve Mí15 ise, öğretmenleri eğitimdeki yenilikleri takip etme konusunda ikna edemediğini şu sözlerle anlatmıştır:

"Nerdeyse eğik yazının kalktığından bile haberi olmayan öğretmenler var, o kadar resmi yazışma, o kadar seminer toplantı... Boş... Ben en çok öğretmenleri yenilikleri takip etme konusunda ikna ederken zorlaniyorum.".

“Örneğin okuma yazma öğretimi... Birçok öğretim metodu var okuma yazma öğretirken. Artık çocuğu daha çok tanımaya ona göre yol seçmeye çalışıyoruz. Ama bizim öğretmenlerimiz çok klasik. 20 yıl önce nasıl okuma yazmayı nasıl öğretiyorsa şimdiki çocuklara da aynısını yapmaya çalışıyor.".

Okul müdürlerinin öğretmenleri ikna etmede zorlandıkları bir diğer konu ise, "idari işlerin yürütülmesi" ile (f:23) ilgilidir. Bununla ilgili olarak ilkokul müdürü Mi11 şunları söylemiştir:

“Öğretmenler, sonuçta nöbet tutmak zorunda, bunu onlar da biliyor, ancak her dönem başında aynı dirençle karşılaşıyoruz, hep bir nöbet tartışması...". (Mİ11) 
“Öğretmenliğin dışında yapmaları gereken daha doğrusu eğitim-öğretim sürecinin bir parçası olarak yapmaları gereken idari görevleri hakkıyla yapmıyorlar. Örneğin komisyonlar... Her şeyi memur yapıyor. Oysa böyle olmaması gerekiyor, okulda yangın çıksa ne yapacă̆ını bilmiyor mesela...". (Mі24)

"İdari işlerin yürütülmesi” ile ilgili olarak okulöncesi müdürlerinden MOÖ25, “Örneğin bir imza atılması gerekiyor, önceden yazı ona gitmiş, ancak yine de hatırlatmak ve uyarmak gerekiyor." derken MOÖ1 "hiçbir idari görevi yapmıyorlar, imza atıyorlar ama neye imza attıklarından haberleri yok, idari işlerle ilgili şeyleri asla okuyup anlamaya yönelik bir çabalar yok." demiştir.

"Veli ile iletişim" (f:15) hem okulöncesi hem de ilkokul müdürleri tarafından öğretmenleri ikna etmede en çok zorlanılan konular arasındadır. Bu hususla ilgili okul müdürlerinin beyanları şu şekildedir:

"Veliler ile iletişim hep problemli. Ya çok samimi olunuyor ya da kapıları tamamen kapal. Oysa bizim ikna etmeye çalıştı̆̆ımı çocuğun faydasına olacak şekilde etkili iletişim kurmalarn.". (MOÖ3)

"Aile katılımı çalışmaları çok önemlidir bizim için. Ancak öğretmenler bunu yük görüyor, her zümre toplantısinda ay ay planlasak bile çoğu öğretmen türlü bahanelerle değil aile katılımı çalışması yapmak veli ile diyalog bile kurmuyor.". (МОÖ9)

"Kimi öğretmen veliyi tanımıyor bile, bu kabul edilemez bir şey ama öbür taraftan öyle öğretmenler var ki velinin evinden çıkmıyor ve bunların hepsi bizim kulağımıza geliyor. Bu konuda etik davranmak gerektiği konusunda ben öğretmenleri ikna edemedim.". (Mİ)

Yine, "proje yazma" (f:15) ve "teknolojiyi verimli kullanma" (f:12) hem okul öncesi hem de ilkokul müdürlerinin öğretmenleri ikna etmekte en çok zorlandıkları konular arasında olduğu tespit edilmiştir. "Proje yazma" ile ilgili Mİ ve MOÖ düşüncelerini şu şekilde dile getirmiştir:

“Artık proje yazma konusu çok önemli, çok seçenek var, Erasmus, E-twinning... Okulu bu anlamda destekleyecek kişiler onlar, mükafatı da var ama hiçbiri öncü olmuyor, biri yazsın da biz de faydalanalım diye düşünüyorlar.". (Mi19)

"Bizim il ARGE proje konusunda çok iyi çalışyor, her dönem başında öğretmenlerime söylüyorum, mutlaka proje istiyorum diye, ama niye ise bu konuda motivasyonlar çok düşük, ikna olmuyorlar.". (MOÖ10)

“Teknolojiyi verimli kullanma”, okul müdürleri tarafından sıklıkla tekrarlanan bir diğer temadır. Bununla ilgili okul müdürlerinden yapılan alıntılar şu şekildedir:

"Bizim öğretmenlerin teknolojiden anladıklarn akıllı tahtada çizgi film izletmek. Birçok teknolojik araç var, ama öğrenmek ve kullanmak konusunda çok dirençliler.". (MOÖ 21)

"Teknolojiyi eğitimine entegre etmek gerek bunu hepimiz biliyoruz ama ben öğretmenlerimi bu konuda yönlendiremiyorum.". (Mi1) 


\subsection{Okul Müdürlerinin Velileri İkna Etmede Zorlandıkları Konular}

Okul müdürlerinin velileri ikna etmekte zorlandıkları konulara ilişkin olarak yapılan içerik analizi sonucunda, 18 okul müdürü velileri her konuda ikna edebildiklerini ifade ederken kalan 66 okul müdürü şu hususlarda zorlandıklarını belirtmişlerdir: "Öğretmen seçimi" (f:21), "eğitim öğretim sürecinde işbirliği" (f:20), "okullardaki maddi kaynakların kısıtlllığı" (f:28) ve "okul kurallarına uyma" (f:13). Müdürlerin velileri en çok öğretmen seçimi ve eğitim-öğretim sürecinde işbirliği gibi veli desteğinin çok önemli olduğu konularda ikna etmekte zorlandıkları anlaşılmaktadır.

"Öğretmen seçimi", özellikle ilkokul müdürlerinin velileri ikna etmekte zorlandığı bir konu olarak ortaya çıkmıştır. Mi15 ve Mí23 bu konu ile ilgili yaşadığı sıkıntıyı şöyle dile getirmiştir:

“Herkes bir öğretmenin adın duyup geliyor, ilkokulda önemli olan öğretmen diyerek geliyor veli. Kontenjan kısıtll, benim okulumdaki bütün öğretmenler iyi, başarıll, seçim yapmayın desek de fayda etmiyor, bunu Milli Eğitimin yasaklaması gerek, baş edemiyoruz.".

“Öğretmen adı duyup evini taşıyan bile var. Bu durumun okuldaki diğer öğretmenler ve öğrenciler açısından yaratacağı problemleri velilere anlatamıyoruz ne yazık ki.".

"Eğitim-öğretim sürecinde işbirliği", hem okul öncesi hem de ilkokul müdürleri tarafından sıklıkla dile getirilmiştir. MOÖ3 bu konu ile ilgili olarak şunları söylemiştir:

"Okul öncesi eğitimin olmazsa olmazı aile katılımıdır. Okulla sürekli iletişim halinde olmalar gerektiği konusunda, okul - aile - öğretmen saç ayă̆ının biri eksik olduğunda öğrencinin sıkıntı yaşayacă̆ı konusunda ve okulun etkinliklerine ve verilen veli eğitimlerine yoğun katılımı sağlamak konusunda velileri ikna edemiyorum.".

Mi̇15 ise, veli ile işbirliğinin önemini vurgulayarak şunları şöyle demiştir:

"Veli çocuğunun başarıl olduğunu istemekte çok haklı ama süreçte bizimle işbirliği yapmıyor mesela öğrenci başarılı olması için bizi desteklemiyor. Örneğin, kitap okuma alışkanlığı kazandırmıyor, ödev takibinde destek olmuyor, yardımo kitap al diyoruz almiyor.".

Okul müdürleri tarafından sıklıkla ifade edilen bir başka konu, "okulun maddi kaynaklarının kısıtlılığı" ile ilgili olmuştur. Bu hususta, okul öncesi eğitim kurumu müdürlerinin sıkıntıları ilkokula oranla daha baskındır. Okul öncesi eğitim kurumu müdürlerinden MOÖ2'nin sözleri şöyledir:

“Ben 15 yıllık idareci olarak velilerimi okulun maddi kaynaklarının kısıtlı olduğu konusunda ikna edemedim. Okulun temizlik işlerini yapacak, temizlik malzemeleri alacak kadar bile bütçemiz yok, üstüne istediğimiz kırtasiye malzemelerini de okuldan bekliyorlar.". 
Velilerle ilgili olarak hem okul öncesi eğitim kurum müdürleri hem de ilkokul müdürleri tarafından benzer sıklıkla vurgulanan son kod "okul kurallarına uyulması" ile ilgilidir. Mì2 ve MOÖ19 bu konu ile ilgili görüşlerini şu şekilde dile getirmiştir.

“Velilerin ne yazık ki birçoğu kural nizam tanımıyor. Ders esnasında sınıflara giriyorlar, çocukların okula düzenli giriş çıkış saatine uymuyorlar. Çocukların kıllk kıyafet kuralları konusunda da hassas değiller ve toplantılara asla gelmiyorlar.". (Mi2)

"Velilerimizle okul kurallarına uymama konusunda çok problem yaşıyoruz, örneğin beslenme listesi önceden belli, ama kesinlikle o listedeki gelmiyor, ya da okula alnnacak malzemeler, hiçbir zaman vaktinde getirmiyor kimse.". (MOÖ19)

\subsection{Okul Müdürlerinin Öğrencileri İkna Etmede Zorlandıkları Konular}

$\mathrm{Bu}$ araştırma kapsamında son olarak temel eğitim kademesinde çalışan okul öncesi ve ilkokul müdürlerinin öğrencileri ikna etmede zorlandıkları konular araştırılmıştır. Bu kategori altında okul öncesi kademesinde çalışan okul müdürleri ile ilkokulda görev yapan okul müdürlerinin görüşlerinin farklılaştığı görülmektedir. İlkokul müdürlerinin öğrencileri “düzenli ders çalışma alışkanlığı" (f: 24) ve "kitap okuma alışkanlığı edinme" (f:15), "kurallara uyma" (f:13) ve "saygılı olma" (f:11) konusunda ikna etmeye çalıştıkları; okul öncesi kademesinde görev yapan okul müdürlerinin ise sadece "beslenme" (f:11) konusunda çocukları ikna etmede zorlandıkları görülmektedir. Okul öncesi yöneticileri çocukların ailelerini ikna etmede daha çok uğraştıklarını vurgulamışlardır. Örnekler şu şekildedir:

Bir ilkokul müdürü (Mİ), öğrencileri “düzenli ders çalışma” konusunda ikna edemediğini şu sözlerle dile getirmiştir: "Öğrenciler düzenli ders çalışma konusunda çok yetersiz. Bu nedenle okul başarımız düşük oluyor. Daha disiplinli ve düzenli çalışmalar konusunda ikna etmekte zorlanıyorum.". Mi29 ise, öğrencileri "kitap okuma alışkanlığı edinme"leri konusunda ikna etmeye çalıştığını anlatırken "Öğrencilerimizle birinci sinıftan itibaren üzerinde en çok konuştuğumuz konu kitap okuma alışkanlığı. Okuma yazmayı bir şekilde öğreniyorlar ama devamı gelmiyor, çünkü alışkanlık edinmiyor." demiştir. Mí6 da Mi29'u destekler şekilde "Bu dönemin başından beri kitap okuma işini çok sıkı tutmaya çalışıyorum ama öğrenciler bu konuda çok tepkisiz, başka birçok nedeni vardır tabi ki, okul müdürünün çabası tek başına yetmeyebilir" demiştir. M17 ise, “...Özellikle 3. sinıftan sonra daha disiplinli çalışmaları gerekiyor, 4. sımıfta çok zorlanıyorlar yoksa ancak öğrenciler üzerinde bu konuda çok söz sahibi olduğumu düşünmüyorum" demiştir.

İlkokul müdürleri, "kurallara uyma” konusunda öğrencileri ikna etmekte zorlandıklarını şu sözlerle dile getirmişlerdir:

“Öğrencilerimizi asla kurallar ve kurallara uymalar konusunda ikna edemiyoruz. Örneğin okula geliş saati, teneffüs bitiş saati, kllik klyafet düzeni... Bir de yer çöp atmama, okul bahçesine yediğinin içtiğinin çöpünü atan çocuklar var.". (Mí22) 
"Kurallar en büyük sorunumuz ve ne yazık ki yaptırımlar hiçbir işe yaramıyor, ne yaparsan yap çocuk kurala uymuyor, ve bu böyle gidiyor, asla değişmiyor.". (Mİ11)

Saygılı olma konusunda ise Mi13 şu ifadeyi kullanmıştır:

"Bu çă̆̆n en büyük sorunu akran zorbalığı, öğrencilerin ne kendilerine ne arkadaşlarına ne de büyüklerine saygısı kalmış. Benim öğrencilerle özellikle 2. sınıftan sonra üzerinde en çok konuştuğum onları ikna etmeye çalıştı̆ım konu dünyadaki her şeye herkese saygılı davranmak, küfür etmemek ve zarar vermemek gibi.".

Öte taraftan "beslenme” daha çok okul öncesi müdürleri tarafından tekrarlanan kod olarak tespit edilmiştir. MOÖ konu ile ilgili olarak şunları dile getirmiştir:

"Bizim yaş grubu çocuklarının iki temel sorunu var biri şeker diğeri teknoloji. Beslenmede yedikleri paketli gidalarn haddi hesabı yok. Aileye söylüyorsun, beni dinlemiyor sen söyle Hocam diyor. Ben gerek sinflarma girerek etkinliklerde gerekse beslenme saatinde konuşuyorum çocuklarla. İkna etmeye çalışıyorum ama iş ailede bitiyor ne yazık ki.".

\section{TARTIŞMA VE SONUÇ}

İkna, her türlü insan etkileşiminde karşımıza çıkan bir olgudur. Bu olguyu beş yaşındaki çocuğunu sağlıklı gıdalar tüketmesi için ikna etmeye çalışan bir annenin özenli çabalarından, ilkokul çağındaki çocuklara kitap okuma ve ders çalışma alışkanlığı kazandırmaya çalışan bir ilkokul öğretmenin girişimlerine kadar hemen her yerde görmek mümkündür. Ancak modern yaşamda bir kişinin veya grubun zihinsel durumunu, tutumlarını, inançlarını veya davranışlarını yazılı veya sözlü iletişim yoluyla değiştirmek için bilinçli ve şuurlu çabalar göstermek gerekmektedir. $\mathrm{Ki}$ bu, ikna etmeyi geliştirilebilecek en önemli becerilerden biri hâline getirmektedir. Bir kimsenin davranış repertuarı ne kadar genişse, davranışsal esnekliği ne kadar fazla ise duygu kontrolü, açık iletişim, güven, kesinlik ve kararlılık düzeyi ne kadar iyi seviyede ise ikna ediciliği o kadar yüksektir.

İleri demokrasi yolunda ilerleyen bugünün dünyasında ikna edici vasıflarla donanmak, ikna edici her çabayı ahlâkî bir zemine oturtmak ve ikna sürecinin etik parametrelerine uygun hareket etmek bir gereklilikten çok zorunluluktur. Zira ikna, demokrasiyi ileri bir merhaleye taşıyan ana payandadır. Demokrasilerde insanları bir araya getirmenin, çatışmaları çözmenin, fikirleri ileri taşımanın, değişimi başlatmanın veyahut da işleri halletmenin, belirli bir konuda ortak bir zemin bulmanın, destek koalisyon inşa etmenin vb. en sağlıklı yolu insanları olaylar, olgular, teklifler, taktikler, mevzuat, strateji vb. birçok konu hakkında ikna etmektir. Ne yazık ki ikna kavramının ulusal alanyazında üzerinde fazla kalem oynatılmamış ve çalışılmamış bir konu olmasının önemli bir boşluk ve eksiklik olduğu düşünülmektedir. Bu bakımdan, bu çalışmanın eğitim kurumlarında ve süreçlerinde ikna kavramını anlamak açısından bir çerçeve sunacağı ve araştırmacıların konuya ilgi ve merakını yoğunlaştıracağı umulmaktadır. 
$\mathrm{Bu}$ bağlamda gerçekleştirilen bu çalışmada, ilkokul ve okul öncesi eğitim kurum müdürlerinin görüssleri alınarak öğretmenleri, velileri ve öğrencileri ikna etmede zorlandıkları konular ortaya konmaya çalışılmıştır. Elde edilen bulgulara göre, okul müdürlerinin öğretmenleri ikna etmede en çok zorlandıkları konuların "eğitimdeki yenilikleri takip etmek”, "idari işler", "veli ile iletişim", "proje yazma" ve "teknolojiyi verimli kullanma" olduğu saptanmıştır. Bu konuların başında "eğitimdeki yenilikleri takip etme" nin gelmesi oldukça manidardır. 16'sı ilkokul ve 14'ü okulöncesi olmak üzere toplam 30 katılımcı okul müdürü "eğitimdeki yenilikleri takip etme"de öğretmenleri ikna etmede zorlandıklarını belirtmişlerdir. Bulgular okul yöneticilerinin, birçok öğretmenin eğitimdeki yenilikleri ve gelişmeleri takip ederek kendilerini geliştirme hususunda endişe verici bir bilgisizlik, ilgisizlik ve kayıtsızlık içerisinde olduklarını düşündüklerini ortaya koymuştur. Katılımcllar öğretmenlerin önemli bir bölümünün kendi bildiklerinden şaşmadıkları, eğitimdeki yeniliklere direnç gösterdikleri, yeniye ve yeniliğe olan ihtiyacın bilincinde ve şuurunda olmadıkları noktasında hemfikirdirler.

Yapılan bazı araştırmalarda (Aslanargun ve Bozkurt, 2012; Genç ve Genç, 2013; Keman, 2019; Özdemir, 2013; TEDMEM, 2019) öğretmenlerin meslekleriyle ilgili gelişmeleri yeterince takip etmedikleri ve mesleki yönden kendilerini geliştirme konusunda eksiklerinin olduğu sonucuna ulaşılmıştır. Oysa içinde bulunduğumuz bilgi ve teknoloji çağında yenilikleri takip etmek ve kendimizi yenilemek mesleki olduğu kadar etik bir zorunluluktur. Üstelik mesleki gelişim, öğretmen yeterlilik alanlarından birini oluşturmaktadır. Bu konuda yapılan çeşitli çalışmalarda (Blandford, 2000; Bolam, 2000; Borko, 2004; Day, 1999; Desimone, 2009; Glatthorn, 1995; Hien, 2008; Hill, 2009; Villegas-Reimers, 2003, Akt. Özdemir, 2013), öğretmenlerin mesleki gelişiminin öğretmenlerin kalitesi ve yeterliliği, öğrencilerin öğrenmesi veya başarısı, okulun gelişimi ve niteliği üzerinde önemli etkisinin ve katkısının olduğu vurgulanmıştır.

Çalışmada katılımcı okul müdürlerinin öğretmenleri ikna etmede güçlük yaşadıkları konulardan birinin de “idari işler" olduğu görülmüştür. 13'ü ilkokul, 10'u okul öncesi olmak üzere toplam 23 okul yöneticisi başta "nöbet tutma, komisyonlarda görev alma, idari konularda isteksiz davranma, mevzuatı ve idari işleri öğrenme konusunda ilgisiz olma ve çaba göstermeme" gibi hususlarda öğretmenleri ikna etmede genel olarak zorlandıklarını vurgulamışlardır. İdari işler, yöneticilerin öncelik sıralamasında üstte yer alır. Ancak öğretmenler ve diğer çalışanlar idari işlerin gereği, lüzumu, iş disiplini ve kurumsallaşma açısından taşıdığı önem gibi hususlarda yöneticiler kadar hassas bir davranış setiyle hareket etmediği bilinen bir hadisedir. Yapılan bazı çalışmalarda da bu çalışmanın bulgularına benzer şekilde okul yöneticilerinin idari süreçlerde öğretmenlerle çeşitli zorluklar ve problemler yaşadıklarına ilişkin bulgulara ulaşılmıştır. Örneğin Aslanargun ve Bozkurt (2012), okul müdürlerinin idari hususlarda öğretmenlerle özellikle “nöbet tutma, derse giriş̧ çııış saatleri, evrak teslimi ve mevzuatı bilmeme" gibi konularda sorunlar yaşadıklarını saptamıştır. Keman (2019) tarafından yapılan çalışmada da okul yöneticilerinin 
öğretmenlerle ilgili yaşadıkları problemler arasında "görev ve sorumluluktan kaçınma, verilen görev ve sorumluluklara itiraz etme, nöbet kurallarına uymama, görev ve sorumluluklarını sinırların bilmeme, belgelerin eksik bırakılması, özen göstermeme" vb. bulgular elde edilmiştir.

Çalışmaya katılan okul müdürlerinin öğretmenleri ikna etmede zorlandıkları hususlardan biri de "veli ile iletişim" konusu olmuştur. Dokuz (9) ilkokul ve altı (6) okul öncesi kurum yöneticisi, öğretmenleri velilerle etkili ve olumlu iletişim kurmaya ikna etme konusunda güçlükler yaşadıklarını düşünmektedir. Katılımcı okul müdürleri, öğretmenlerin veli ile iletişimi profesyonel bir çerçevede yürütemediklerini, bu ilişkiyi öğrenciye faydası olacak şekilde kullanamadıklarını dile getirmişlerdir. Oysa, Patrikakou ve Weissberg'in (2000) de vurguladığı gibi, veli-öğretmen ilişkisinin niteliği, ilişkinin sıklığı ya da miktarından çok öğrencinin başarısı ve olumlu davranışları açısından önemlidir. Okul sosyal bir örgüttür ve veli bu örgütün önemli dinamiklerinden biridir. Bu konuda yapılan araştırmalar (Aslan, 1994; Oğan, 2000; Saraçoğlu, 2002) velilerin okula yönelik ilgisizliklerinde öğretmenlerin olumsuz tavırları, çocuğun başarısızlığı, veli toplantılarının yeterince önemsenmemesi, velilere gerekli zamanın ayrılmaması gibi sebeplerin olduğunu göstermektedir.

Buna göre, öğretmenlerle veliler ya da aileler arasındaki iletişimi güçlendirmeye yönelik çalışmalar, öğrencilerin okul başarısını yükseltebileceği gibi okulda ve sınıfta disiplin sorunlarının yaşanmasını da engelleyebilir, en azından azaltabilir. İstenmeyen davranışların en aza indirilebilmesi için öğretmen, yönetici ve ailenin ortak çaba içinde olmaları, olaylara anlayışla yaklaşmaları, ilgi ve ihtiyaçlarına cevap veren programlarla öğrencilerin motive edilmeleri gerekmektedir (Ovacık, 1991, 34; Özdayı, 2004, 375; Akt.: Çalışkan ve Ayık, 2015).

"Proje yazma ya da proje etkinliklerine katılma" konusunda öğretmenleri ikna etmek, çalışmanın katılımcısı ilkokul müdürlerinin önemli bir bölümü (yedi ilkokul müdürü, sekiz okulöncesi müdürü) tarafından dile getirilen müşterek bir zorluktur. Okul müdürleri, proje çalışmaları gerçekleştirme konusunda öğretmenlerin ilgi ve motivasyon düzeylerinin düşük olduğu kanaatindedirler. Oysa yapılan araştırmalar, proje çalışmalarının öğrencilerin sosyalleşmelerine (Çetin ve Şengezer, 2013), gerçek hayat problemlerini çözme becerisi kazanmalarına (Güven, 2013), bilimsel süreç becerilerini arttırmalarına (Şahin, Güven ve Yurdatapan, 2013) katkı sağladığını göstermektedir.

"Teknolojiyi verimli kullanma" ise, hem ilkokul hem de okul öncesi yöneticiler tarafından öğretmenleri ikna etmede zorluk çekilen faktörlerden biri olarak dile getirilmiştir. Teknoloji yeterlilikleri, öğretmen yeterliklerinin temel ve ayrılmaz bir parçasıdır. Okul müdürleri, öğretmenlerin teknolojiyi eğitsel amaçlarla kullanma hususunda eksiklikleri bulunduğunu dile getirmektedir. Bu konuda yapılan bazı çalışmalarda öğretmenlerin öğrenmeöğretme süreçlerinde öğretim teknolojilerinden veya eğitim araç-gereçlerinden yararlanma düzeylerinin ve tutumlarının orta düzeyde olduğu sonucuna ulaşılmıştır (Bozkurt ve 
Cilavdaroğlu, 2011; Göksu ve Atmaca, 2019; Köseoğlu ve Soran, 2005; Şahin, 2014). Bu bulgular da hali hazırda bu çalışmada okul yöneticilerinin teknolojiyi verimli ve etkili kullanma konusunda öğretmenleri ikna etmede zorlandıkları bulgusunu desteklediği söylenebilir.

Çalışmada alt problem olarak belirlenen ve araştırılan hususlardan biri de okul müdürlerinin "velileri" ikna etmede zorluk yaşadıkları konular olmuştur. Katılımcıların görüşlerine göre bu konuların "öğretmen seçimi", "eğitim-öğretim sürecinde işbirliği", "okulun maddi kaynaklarının kısıtllı̆̆ı" ve "okul kurallarına uyma" olduğu tespit edilmiştir.

Katılımcı okul müdürlerinin velileri ikna etmekte en çok zorlandıkları konuların başında "öğretmen seçimi" ( $\mathrm{f}=15$ ) gelmiştir. Öğretmen seçimi, özellikle ilkokul kademesinde Türkiye'de giderek artan bir öneme sahip, hatta bazı durumlarda sorun hâline gelmiştir. Nitekim yapılan araştırmalar (Şenaras ve Çetin, 2018; Türk ve Kıroğlu, 2018) velilerin öğretmen seçme, değiştirme ve belli bir sınıfa kayıt yaptırma gibi konularda okul yönetimine baskı uyguladıklarını göstermektedir. Bilindiği üzere Türk Eğitim Sistemi, velilerin çocuklarının geleceği için okul seçme konusunda bir seçim yapmalarını doğrudan sağlamasa da veliler dolaylı ve gayri resmi olarak okul tercihinde bulunabilmektedir. Öğrencilerin ilkokula kabulünde ADNKS (Adrese Dayalı Nüfus Kayıt Sistemi) esas alınması dolayısıyla okul tercihi konusunda kısıtlanan veliler öğretmen seçimi konusunda özgür olmak isteyebilmektedir.

Çalışmanın bulgularına göre, okul yöneticilerinin (18'i ilkokul ve 20'si okul öncesi olmak üzere toplam 38 okul yöneticisi) "eğitim-öğretim sürecinde işbirliği yapma" ve "okulun maddi kaynaklarının kısıtlılığı" konularında da velileri ikna etmede güçlük yaşadıkları görülmüştür. Velilerin ya da ailelerin eğitim-öğretim sürecine katılımları, eğitim hizmetinin niteliği bakımından oldukça önemlidir. Gwiazdowska'nın (2014) da belirttiği gibi, öğrencilerin kişiliklerini şekillendiren ve başarılarını etkilemede son derece önemli olan iki ortam, "aile" ve "okul"dur. Bu iki topluluğu entegre etme ve aralarında işbirliği kurma becerisi, öğrencilerin eğitim ve öğretim süreçlerindeki mutluluğu ve başarısı için anahtar rolündedir. Oysa bu konuda yapılan bazı çalışmaların bulgularına göre (Aykol, 2019; Can ve Kılı̧, 2019; Dağlı ve Han, 2017; Memduhoğlu ve Meriç, 2014; Ünal, Yıldırım ve Çelik, 2010) öğrenci velilerinin okulun akademik, sosyal ve ekonomik sorunları ve gelişmesi yönünde istenen düzeyde katılım göstermediklerini, gerekli işbirliğini gerçekleştirmediklerini göstermektedir.

Okul yöneticilerinin velileri ikna etmede zorlandıklarını ifade ettikleri diğer bir konu ise “okul kurallarına uyma” olmuştur. İlkokul müdürlerinin 7'si, okulöncesi kurum müdürlerininse 6'sı bu konuda velileri ikna etmede sorun yaşadıklarını not etmiş̧tir. Katılımcılar, özellikle öğrenci velilerinin derslerin işlenmesi sırasında sınıflara girmeleri, toplantılara katılım gösterme konusunda duyarlı olmamaları, çocuklarının okula giriş ve çıkış saatlerine uymama ve kılık kıyafet kurallarına dikkat etmeleri konusunda çocukları ile yeterince ilgilenmemeleri vb. okul kurallarına uyma ile ilgili konularda onları ikna etmede güçlük yaşadıklarını vurgulamışlardır. 
Bu konuda yapılan bazı çalışmaların (Can ve Kılıç, 2019; Çetin; 2019; Sarpkaya, 2007; Ünal, Yıldırım ve Çelik, 2010) bulguları da bunu destekler niteliktedir.

Çalışmada elde edilen bulgulardan bir diğer de okul yöneticilerinin "öğrencileri" ikna etmede zorlandıkları konulara ilişkin görüşlerdir. Çalışmaya katılan okul müdürlerinin öğrencilerini ikna etmekte en çok güçlük yaşadıkları konular "düzenli olarak ders çalışma", "kitap okuma alıskanlığı edinme", "kurallara uyma", "saygılı olma" ve "sağhklı beslenme" başlıkları altında toplanmıştır. Bu konuların başında "düzenli olarak ders çalışma"nın gelmesi oldukça manidardır. 24 okul müdürü öğrencilerine düzenli biçimde ders çalışma alışkanlığı kazandırma noktasında sorun yaşadıklarını ifade etmiştir. Konu ile ilgili yapılan bazı araştırmaların bulguları (Demiroğlu, 2007; Akarçay, Demirzen ve Akhan, 2013) da göstermektedir ki, öğrenciler iyi bir gelecek için ders çalışmanın öneminin farkında olup ders çalışmayı sevmekte, ancak sıkıcı bulmakta ve ders çalışmayı yapılması zorunlu bir görev olarak görmektedirler. Bunun yanı sıra bazı çalışmalarda (Bilasa, 2016; Özcan, 2006) da öğrencilerin orta düzeyde ders çalışma alışkanlığına ya da tutumuna sahip oldukları bulgularına rastlanmıştır. Yukarıda belirtilen çalışmaların bulguları, bu araştırmanın çalışma grubundaki okul yöneticilerinin düzenli biçimde ders çalışma hususunda öğrencileri ikna etmede zorlandıkları bulgusunu teyit eder niteliktedir.

Okul müdürlerinin, öğrencilerin kitap okuma alışkanlığı edinmesini istemesi, ancak bu konuda öğrencileri ikna etmede güçlük yaşadıklarını belirtmelerinin de oldukça önemli bir bulgu olduğu söylenebilir. Dağ'ın (2017) yürüttüğü bir çalışmada, ilkokul 4. sınıf öğrencilerinin \% 98'i okumanın önemli olduğuna inandığını ve \% 88,2'si okumayı "eğlenceli" bir aktivite olarak tanımladığını belirtmiş; buna karşın, ne sıklıkla kitap, gazete ve dergi okudukları sorulduğunda, öğrencilerin neredeyse yarısı “ara sıra” yanıtını vermiştir. Buna benzer şekilde bu konuda yapılan çalışmalarda (Bayat ve Çetinkaya, 2018; İşcan, Arıkan ve Küçükaydın, 2013; Katrancı; 2015; Şahin; 2012) ilkokul ya da ortaokul öğrencilerinin kitap okuma sıklıklarının ya da alışkanlıklarının "orta düzeyde", "ortanın biraz üstünde" veya "ara sıra" sıklığında olduğuna ilişkin bulgular elde edilmiştir.

Türkiye İstatistik Kurumu'nun (2013) araştırma raporuna göre, günde altı saat televizyon izleyip üç saat internete giren Türk insanı kitap okumaya sadece bir dakika zaman ayırmaktadır. Buna göre Avrupa' da yüzde 21 olan okuma oranı, Türkiye'de yüzde $0,1^{\prime}$ dir. Bu okuma oranıla dünya ülkeleri arasında 86. sırada yer almaktadır. Dünyada en fazla kitap okuyan ülkelerin başında yüzde 21'le İngiltere ve Fransa yer alırken, bu ülkeleri yüzde 14'le Japonya, yüzde 12'yle Amerika ve yüzde dokuzla İspanya takip etmektedir. TUIKK verilerine göre kitap, ihtiyaç listesinin 235. sırasında yer almaktadır². Toplumun yüzde 75'i kitap okumamakta, yüzde $40^{\prime} 1$ ise hiç kütüphaneye gitmemektedir (Ortaş, 2007). Bu çalışmada da “kitap okuma alışkanlığı

\footnotetext{
${ }^{2}$ Bu bilgi, www.tk.org.tr/index.php/TK/article/download/412/404 web sitesinden temin edilmiştir. 
edinme", 15 ilkokul yönetici tarafından öğrencileri ikna etmede zorlanılan konulardan biri olarak dile getirilirken okulöncesi yöneticileri tarafından belirtilmeyen bir konu olmuştur. Oysa, her ne kadar okuma yazmaya hazırlık döneminde olsalar da okul öncesi, kitap sevgisi ve alışkanlığı kazanmanın temellerinin atıldığı bir dönemdir. Bu dönemdeki çocuklar okumayı henüz bilmeseler de kitaplardaki görseller vasıtasıyla hayal dünyaları zenginleştirilebilmekte, yaratıcı düşünmeleri beslenebilmektedir.

Disiplin ve sınıf kuralarına uyma, hem okulöncesi hem de ilkokul döneminde eğitim hizmetinin niteliği açısından ve etkili bir sınıf yönetimi ortaya koymak bakımından hayati öneme sahip bir konudur. Bu çalışmada, okul yöneticilerinin öğrencileri "kurallara uyma" konusunda ikna etmede zorlandıkları ortaya çıkmıştır. Sadık ve Aslan'ın (2015) yürüttüğü bir araştırmada da öğretmenlerin sınıf içinde en sık karşılaştıkları disiplin problemlerinden birinin sınıf kurallarına uymama olduğu bulgulanmıştır. Etkili bir sınıf yönetimi, kuralların açık ve net bir biçimde ortaya konmasına ve bu kuralların süreğenlik arz etmesine bağlıdır (Bear, 1998; Carter ve Doyle, 2011). Sınıf ve okul kurallarına uyulmasını sağlama okul yöneticilerinin ve öğretmenlerin, öğrenci velileriyle işbirliği içinde gerçekleştirmeleri gereken önemli bir husustur. Sınıf yönetimi alanyazınında bu problemi çözmede kullanılabilecek çeşitli yaklaşımlar ya da stratejiler (Ünsal, 2017; Yüksel, 2017) bulunmaktadır.

Okul müdürlerinin öğrencileri iknada zorluk yaşadıklarını ifade ettikleri konulardan bir diğeri "saygılı olma" değeri olmuştur. Bu konuda genellikle ilkokul yöneticilerinin şikâyetçi oldukları görülmüş ve katılımcılar öğrencilerin genellikle birbirlerine ve öğretmenlerine karşı şiddet, zorbalık ve küfür etme gibi saygısız davranışlar gösterdiklerini ifade etmişlerdir. Külünkoğlu (2017) da yaptı̆̆ı çalışmada bu bulguya benzer şekilde, ortaokul öğrencilerinin öğretmenlere, yöneticilere ve birbirlerine karşı çeşitli saygısız davranışlarda bulunduklarını belirtmiştir. Kuşkusuz, küreselleşme ve teknolojinin etkisiyle toplumsal değer yargılarındaki bozulma nedeniyle saygı toplumsal yaşamımızda giderek önemi artan değerlerden biri haline gelmiştir. Saygı değeri, sadece bireylerin birbirlerine karşı özenli, ölçülü ve dikkatli olması olarak algılanmamalıdır. Tracey'e (1996) göre saygı; bireyin kendine, çevresine, doğaya, ülkesine, bayrağına, tarihine, kültürüne karşı hissedilen bir duygudur. Ayrıca diğer insanlara karşı hoşgörülü davranılması, onların dinlenilmesi ve onların bakış açılarının anlamaya çalışılmasını içeren kabullenme değeri saygı değerinin içerisinde yer almaktadır (Duran ve Bitir, 2020, 2).

Okul müdürlerinin, özellikle de okul öncesi kurum yöneticilerinin öğrencileri ikna etmede gücük yaşadıkları konulardan birisi "sağlıklı beslenme" şeklindedir. Sağlıklı bir yaşam, her insanın en temel ihtiyacıdır. Yeterli, dengeli ve sağlıklı beslenme, çocukluk döneminde kazanılan ve şekillenen bir rutindir. Hatta çocuğun hayatının sonraki dönemlerini etkileyen ve ileride ortaya çıkacak beslenme sorunlarına temel teşkil eden bir güce sahiptir (Kaya, 1999). Ayrıca sağliklı beslenme, temel eğitim dönemindeki çocukların gelişimi ve öğrenme 
potansiyelleri açısından da son derece mühim bir meseledir. Bu bakımdan, sağlıklı beslenme konusunda bireylerin bilinçli olmasının ve bu alışkanlığı kazanmalarının sağlanması başta ebeveynler olmak üzere okul öncesi ve ilkokul yöneticilerinin ve öğretmenlerin önemli görev ve sorumlulukları arasında yer almaktadır. Bu konuda okullarda ailelerle işbirliği içinde ve öğrencilerin de aktif katılımının sağlandığı etkinlikler, projeler ve farkındalık çalışmaları yapılması önerilebilir. Nitekim çeşitli Avrupa ülkelerinde okul öncesi veya ilkokul programlarına beslenme eğitiminin entegre edildiği, bu sayede öğrencilere dengeli ve sağlıklı beslenme, besin hijyeni, besin güvenliği vb. konularda bilgi ve farkındalık kazandırıldığı bulunmuştur (Eat Well, 2001; Saksvig vd., 2005; Akt.: Akder, Meseri ve Çakıroğlu, 2018).

\section{KAYNAKLAR}

Akarçay, G., Demirezen, S., \& Akhan, N. (2013). İlköğretim öğrencilerinin ders çalışma üzerine algıları. Karadeniz Sosyal Bilimler Dergisi, 5(8), 169-183.

Akder, R.N., Meseri, R., \& Çakıroğlu, F.P. (2018). Okul çağı çocukluk döneminde beslenme eğitimi. Ankara Sağlık Bilimleri Dergisi, 7(2), 1-10.

Akturan, U., \& Esen, A. (2008). Fenomenoloji. Ed.: T. Baş ve U. Akturan, Nitel araştırma yöntemleri (s. 83-98), Ankara: Seçkin Yayıncılık.

Aristoteles (2008). Retorik (Çev.: M.H. Doğan). İstanbul: Yapı Kredi Yayınları.

Aslan, B. (1984). Ankara merkez ilçelerinde temel eğitim birinci kademe düzeyinde okul-aile ilişkileri. Yayımlanmamış Doktora Tezi, Hacettepe Üniversitesi, Ankara.

Aslan, S. (2019). İlkokul 4. sınıf öğrencilerinin duygu ve düşüncelere sayg1 ile hoşgörü tutumları ve görüşlerinin incelenmesi. E-Uluslararası Eğitim Araştırmaları Dergisi, 10(2), 80-97.

Aslanargun, E. , \& Bozkurt, S. (2012). Okul müdürlerinin okul yönetiminde karşılaştığı sorunlar. Gaziantep Üniversitesi Sosyal Bilimler Dergisi, 11(2), 349-368.

Aykol, B. G. (2019). Öğretmen ve veli görü̈slerine göre ailenin eğitime katılımı. Yayımlanmamış Yüksek Lisans Tezi, Marmara Üniversitesi-İstanbul Sebahattin Zaim Üniversitesi, İstanbul.

Bayat, N., \& Çetinkaya, G. (2018). Ortaokul öğrencilerinin okuma alışkanlıkları ve tercihleri. İlköğretim Online, 17(2), 984-1001.

Bear, G. G. (1998). School discipline in the United States: Prevention, correction, and long-term social development. School Psychology Review, 27(1), 14-32.

Bilasa, P. (2016). Ortaöğretim öğrencilerinin öğrenme ve ders çalışma stratejilerinin çeşitli değişkenler açısından incelenmesi: Ankara Hacı Ömer Tarman Anadolu Lisesi örneği. Yüzüncü Yıl Üniversitesi Ĕ̆itim Fakültesi Dergisi, 13(1), 79-122.

Bozkurt, A., \& Cilavdaroğlu, A.K. (2011). Matematik ve sınıf öğretmenlerinin teknolojiyi kullanma ve derslerine teknolojiyi entegre etme algıları. Kastamonu Eğitim Dergisi, 19(3), 859-870. 
Büyükkantarcioğlu, N., \& Yarar, E. (2006). Dil ve ikna: Türk politika söyleminde ikna edici önerme yapıları (s. 91-113). Dilbilim Araştırmaları, İstanbul: Boğaziçi Üniversitesi Yayınları.

Can, E., \& Kılıç, Ş. (2019). Okul öncesi eğitim: temel sorunlar ve çözüm önerileri. Milli Ĕ̆itim, 48(1), 483-519.

Carter, K., \& Doyle, W. (2006). Classroom management in early childhood and elementary classrooms. Eds. C.M. Evertson, C.S. Weinstein, Handbook of Classroom Management: Research, Practice, and Contemporary Issues (pp. 373-406), Lawrence Erlbaum Associates Publishers.

Cialdini, R. (2003). İknanın psikolojisi: Teori ve pratik bir arada (Çev.: Y. Fletcher). İstanbul: MediaCat Yayıncilık.

Creswell, J. W. (2007). Qualitative inquiry and research design: Choosing among five traditions. California: SAGE.

Çalışkan, N., \& Ayık, A. (2015). Okul aile birliği ve velilerle iletişim. Ahi Evran Üniversitesi Sosyal Bilimler Enstitüsü Dergisi, 1(2), 69-82.

Çetin, O., \& Şengezer, B. (2013). Ortaokul öğrencilerinin proje çalışmalarına ilişkin görüşleri. Ege Eğitim Dergisi, 14(1), 24-49.

Çetin, Ş. (2019). Okul müdürlerinin karşılaştığı sorunlar: nitel bir inceleme. Kastamonu Education Journal, 27(4), 1637-1648.

Dağ, N. (2017). The reading profile of Turkish primary school students. International Journal of Instruction, 10(4), 293-306.

Dağ, N. (2019). Aylak yazılar. Ankara: Yayınevi Yayınları.

Dağlı, A., \& Han, B. (2017). Okul müdürlerinin görüşlerine göre Diyarbakır ili eğitim sorunları ve çözüm önerileri. Dicle Üniversitesi Ziya Gökalp Eğitim Fakültesi Dergisi, 32, 892-904.

Demiroğlu, M.A. (2007). Ders çalışmaya ilişkin öğrenci görüşleri: İlköğretim 5. sınıf örneği. Milli Eğitim Dergisi, 173, 112-124.

Duran, E., \& Bitir, T. (2020). İlkokul öğretmenleri, öğrencileri ve velilerinin değer algıları. Hacettepe Üniversitesi Eğitim Fakültesi Dergisi. Advance online publication. DOI: 10.16986/HUJE.2020058224

Genç, M., \& Genç, T. (2013). Öğretmenlerin mesleki gelişmeleri takip etme durumları: Fatih projesi örneği. Ahi Evran Üniversitesi Kırşehir Eğitim Fakültesi Dergisi (KEFAD), 14(2), 61-78.

Glesne, C. (2013). Nitel araştırmaya giriş (Çev. Edt.: P. Yalçınoğlu ve A. Ersoy). Ankara: Anı Yayıncilik.

Göksu, H., \& Atmaca, S. (2019). Öğretmenlerin ve öğretmen adaylarının mobil eğitim uygulamalarına yönelik tutumları. Folklor/Edebiyat, 25(97), 105-115.

Gwiazdowska, S. (2014). Cooperation between school and family as a key to student success. Polish Journal of Social Science, 9(1), 225-234. 
Güven, İ. (2013). Fen ve teknoloji öğretmen adaylarının proje yönetimi deneyimlerinin değerlendirilmesi. Hacettepe Üniversitesi Eğitim Fakültesi Dergisi, Özel Sayı(1), 204-218.

İşcan, A., Arıkan, İ.B., \& Küçükaydın, M.A. (2013). İlköğretim ikinci kademe öğrencilerin kitap okuma alışkanlıkları ve okumaya ilişkin tutumları. Uluslararası Avrasya Sosyal Bilimler Dergisi, 4(11), 1-16.

Jowett, G. S., \& O'Donnell, V. (2012). Propaganda and persuasion (5th Edition). SAGE Publications, Inc.

Katrancı, M. (2015). İlkokul dördüncü sınıf öğrencilerinin kitap okuma motivasyonlarının incelenmesi. Ana Dili Ĕ̆itimi Dergisi, 3(2), 49-62.

Kaya, M. (1999). Anne-baba eğitimi destekli beslenme eğitiminin 3-6 yaş grubu çocuklarn beslenme bilgisi ve davranışlarına etkisi. Yayınlanmamış Yüksek Lisans Tezi, Gazi Üniversitesi, Ankara.

Keman, F.Y. (2019). Göreve yeni başlayan okul yöneticilerinin karşılaştıkları sorunlar ve çözüm önerileri. Yayınlanmamış Yüksek Lisans Tezi, Sebahattin Zaim Üniversitesi, İstanbul.

Köseoğlu, P., \& Soran, H. (2005). Biyoloji dersinde araç-gereç kullanımı açısından öğretmen yeterlilikleri. Hacettepe Üniversitesi Eğitim Fakültesi Dergisi, 28, 150-158.

Külünkoğlu, T. (2017). Ortaokul öğretmenlerinin öğretmene saygı değerine ilişkin görüşleri. Asya Studies-Academic Social Studies/Akademik Sosyal Araştırmalar, 1, 11-22

Memduhoğlu, H. B., \& Meriç, E. (2014). Okul müdürlerinin eğitim yönetiminin işlevleri bağlamında yönetim sürecinde karşılaştıkları temel sorunlar. Uluslararası Sosyal Araştırmalar Dergisi, 7(33), 653-666.

Miles, M.B., \& Huberman, A.M. (1994). Qualitative data analysis. Thousand Oaks, CA: Sage Publication.

Oğan, M. (2000). Okul, okul-aile birliği ve velilerin eğitim beklentisi. Yayınlanmamış Yüksek Lisans Tezi, Ankara Üniversitesi, Ankara.

Ortaş, İ. (2007). Kitap okuru bir toplum muyuz-1? 14.12.2014 tarihinde http://turkoloji.cu.edu.tr/GENEL/ibrahim_ortas_kitap_okuru.pdf adresinden temin edilmiştir.

Özcan, G. (2006). İlköğretim dördüncü ve beşinci sınıf öğrencilerinin ders çalışma alışkanlıkları ve ortamlarının incelenmesi. Yayımlanmamış Yüksek Lisans Tezi, Marmara Üniversitesi, İstanbul.

Özdemir, S. M. (2013). Exploring the Turkish teachers' professional development experiences and their needs for professional development. Mevlana International Journal of Education, 3(4), 250-264. 
Patrikakou, E. N., \& Weissberg, R.P. (2000). Parents' perceptions of teacher outreach and parent involvement in children's education. Journal of Prevention and Intervention in the Community, 20(1-2), 103-119.

Patton, M. Q. (1990). Qualitative evaluation and research methods. USA: Sage Publication.

Sadık, F., \& Aslan, S. (2015). İlkokul sınıf öğretmenlerinin disiplin problemleri ile ilgili görüşlerinin incelenmesi. Turkish Studies, 10(3), 115-138.

Saraçoğlu, M. (2002). Etkin sınıf yönetimi, öğrenci-öğretmen-veli üçgenini sinıf yönetimine etkisi. Yayınlanmamış Yüksek Lisans Tezi, Dumlupınar Üniversitesi, Kütahya.

Sarpkaya, P. (2007). Yönetici, öğretmen, öğrenci ve velilere göre resmi liselerdeki öğrenci disiplin sorunlarının nedenleri. Pamukkale Üniversitesi Ĕ̆itim Fakültesi Dergisi, 2(22), 110-121.

Simons, H.W., Morreale, J., \& Gronbeck, B. (2001). Persuasion in society. SAGE Publication. 28.11.2019 tarihinde $\quad$ https://us.corwin.com/sites/default/files/upmbinaries/2741_SimonsMarketingSampler.pdf adlı linkten temin edilmiştir.

Şahin, A. (2012). İlköğretim 4 ve 5. sınıf öğrencilerinin kitap okuma alışkanlıklarının sosyoekonomik düzeylerine göre incelenmesi. Türk Eğitim Bilimleri Dergisi, 10(2), 367-388.

Şahin, A. (2014). Öğretim materyallerinin öğrenme-öğretme sürecindeki işlevine ilişkin öğretmen görüşlerinin analiz. Kastamonu Eğitim Dergisi, 23(3),995-1012.

Şahin, F., Güven, İ., \& Yurdatapan, M. (2013). Proje tabanlı eğitim uygulamalarının okul öncesi çocuklarında bilimsel süreç becerilerinin gelişimine etkisi. M.Ü. Atatürk Eğitim Fakültesi Ĕ̆itim Bilimleri Dergisi, 33, 157-176.

Şenaras, B., \& Çetin, Ş. (2018). Okul müdürleri ile öğretmenlerin algılarına göre ilk ve ortaokullarda veli baskısı: Nitel bir araştırma. Milli Eğitim, 220, 157-176.

Şişman, M. (2002). Öğretim liderliği. Ankara: PegemA Yayıncılık.

Ünal, A., Yıldırım, A., \& Çelik, M. (2010). İlköğretim okulu müdür ve öğretmenlerinin velilere ilişkin algılarının analizi. Selçuk Üniversitesi Sosyal Bilimler Enstitüsü Dergisi, 23, 261-272.

Ünsal, H. (2017). Okul ve sınıfta disiplin. Edt. M.Ç. Özdemir, Sınıf yönetimi (s. 230-263). Ankara: PegemA Akademi.

TEDMEM. (2019). TALIS 2018 sonuçları ve Türkiye üzerine değerlendirmeler (TEDMEM Analiz Dizisi 6). Ankara: Türk Eğitim Derneği Yayınları.

Türk, H., \& Kıroğlu, K. (2018). Ailelerin sınıf öğretmenlerine uyguladığı mobbing davranışları. Abant İzzet Baysal Üniversitesi Ĕ̆itim Fakültesi Dergisi, 18(4), 2357-2389.

Von Eckartsberg, R. (1986). Life-world experience: Existential-phenomenological research approaches in psychology. Washington, D.C.: Center for Advanced Research in Phenomenology and University Press of America. 
Willingham, D. T. (2009). Whay don't students like school? A cognitive scientist answers questions about how the mind works and what it means for the classroom. San Francisco, CA, US: JosseyBass.

Yaman, T. (2011). Yöneticilerin paternalist (babacan) lider davranışlarının çalışanların örgütsel özdeşleşmelerine, iş performanslarma ve işten ayrnlma niyetlerine etkisi: Özel sektörde uygulama. Yayınlanmamış Yüksek Lisans Tezi, Ankara: Kara Harp Okulu.

Yüksel, A.H., Sandıkçığlu, B., Onay, A., \& Yılmaz, A. (1994). İkna edici iletişim. M. Oyman (Edt.), Eskişehir: Anadolu Üniversitesi Yayınları.

Yüksel, G. (2017). Sınıfta kurallar geliştirme ve uygulama. G. Yüksel ve S. Büyükalan (Edt.), Sınıf yönetimi (s.147-170), Ankara: PegemA Akademi.

Yıldırım, A., \& Şimşek, H. (2013). Sosyal bilimlerde nitel araştırma yöntemleri (9. baskı). Ankara: Seçkin Yayıncılık.

Etik Kurul Kararı: Mersin Üniversitesi Sosyal ve Beşeri Bilimler Etik Kurulu Onay Belgesi 25.03.2020 tarihinde 034 karar no ile alınmış ve araştırma etik yönden uygun bulunmuştur. 